\title{
Upward Continuation and Reduction to Pole Process on Aeromagnetic Data of Ibadan Area, South-Western Nigeria
}

\author{
S. A. Ganiyu ${ }^{1}$, B. S. Badmus ${ }^{1}$, M. O. Awoyemi ${ }^{2}$, O. D. Akinyemi ${ }^{1} \&$ Oluwaseun T. Olurin $^{1}$ \\ ${ }^{1}$ Department of Physics, University of Agriculture, Abeokuta, Ogun State, Nigeria \\ ${ }^{2}$ Department of Physics, Obafemi Awolowo University, Ile-Ife, Osun State, Nigeria \\ Correspondence: Oluwaseun T. Olurin, Department of Physics, University of Agriculture, Abeokuta, P.M.B. 2240, \\ Abeokuta, Ogun State, Nigeria. Tel: 234-806-660-0703. E-mail: olurin@physics.unaab.edu.ng \& \\ stolurin@yahoo.com
}

Received: June 25, 2012 Accepted: July 9, 2012 Online Published: September 6, 2012

doi:10.5539/esr.v2n1p66 URL: http://dx.doi.org/10.5539/esr.v2n1p66

\begin{abstract}
A magnetic survey of Ibadan area in the South-Western part of Nigeria was performed as part of the largest airborne geophysical survey blocks flown between 2003 and 2010 by the Nigeria Geological Survey Agency. Two magnetic data enhancement procedures were employed to determine their effectiveness in characterizing the study area. The upward continuation together with reduction to Pole technique significantly improve the interpretation of magnetic data in terms of discriminating between shallow and deep magnetic sources within the study area.
\end{abstract}

Keyword: aeromagnetic, magnetic sources reduction to pole and upward continuation

\section{Introduction}

The magnetic method is frequently used to search for buried magnetic materials (Walsh, 1989). Another common application is in the determination of the probable depth to basement beneath sedimentary rocks (Birch, 1984). The location of shallow magnetic materials such as buried container, pipes, metals debris are also enhanced with magnetic data processing together with enhancement procedures which substantially improve the interpretations of the magnetic data. The field magnetic data are processed by mathematical operations such as the Fourier transforms which is a precursor of spectral analysis readily programmed for computers using a 'Fast Fourier transform' (FFT) algorithm. FFT subroutine can thus be routinely built into data processing programs in order to carry out spectral analysis of geophysical waveforms, profiles or some type of map (contour, wire mesh, shaded etc) and interpreted for subsurface magnetic sources. If detailed interpretation is desired, a residual magnetic anomaly due to an object of interest may be determined from a regional magnetic field. The residual magnetic anomaly is modeled by computer methods to determine the depth, geometry and magnetic susceptibility of the source of the anomaly. These models provide a basis of a geological interpretation of the subsurface.

For example, Reduction to pole technique of magnetic data transforms asymmetric forms, whereas upward continuation of data attenuates high wave number anomalies associated with shallow magnetic sources allowing easy interpretation of deep magnetic sources.

Upward continuation is a method to separate a regional magnetic anomaly resulting from deep sources from the observed magnetic. Reduction to the pole (RTP) transforms an observed TMI anomaly into an anomaly that would be measured at the north magnetic pole.

This relocates extreme magnetic anomalies to be over their sources, thus making magnetic interpretation easier. The upward continuation operator (Jacobsen, 1987) is a numerically stable operation, and it forms a natural link between ground surveys and airborne surveys. There are two key problems with the method: (1) conventional upward continuation over attenuates the regional, and (2) the height must be known

In this study, the reduction to pole technique and upward continuation process were performed on the aeromagnetic data of Ibadan area located in the south-western part of Nigeria. Aeromagnetic data shows variations in the magnetic field of the earth, which are attributed to the change in the magnetic susceptibility of near surface rocks. 


\section{Materials and Methods}

The magnetic data used in this study was obtained from Geological survey of Nigeria on a scale of 1:100 000. The data was obtained along a series of NE-SW with a flight line spacing of $500 \mathrm{~m}$ and tine line spacing of $5000 \mathrm{~m}$. The flight line direction is in the direction $135^{\circ}$ azimuth and the tie line direction is in $45^{\circ}$ azimuths. The flying altitude was $80 \mathrm{~m}$ above the terrain. The average magnetic inclination and declination across the survey was $9.75^{\circ}$ and $1.30^{\circ}$ respectively. The geomagnetic gradient was removed from the data using the International Geomagnetic Reference Field formula (IGRF) of 2008. The map of the study area is published on the scale of 1:100000 (i.e. $1 \mathrm{~cm}$ on the map $=1 \mathrm{~km}$ on ground). The topographical detail of the map was based on 1:100000 topographical series of the Federal Surveys of Nigeria.

The study area extends from latitude $7^{\circ} 00^{\prime} \mathrm{N}$ to $7^{\circ} 30^{\prime} \mathrm{N}$ and longitude $3^{\circ} 30^{\prime} \mathrm{E}$ to $4^{\circ} 00^{\prime} \mathrm{E}$ in the south western part of Nigeria.

\subsection{Location of the Study Area}

The study area is Ibadan area. Ibadan is the capital city of Oyo state. Oyo state is an inland state in south-western Nigeria. It is bounded in the north by Kwara state, in the east by Osun state, in the south by Ogun state and in the west partly by Ogun state and partly by the republic of Benin. Ibadan is the largest indigenous city in West Africa and is located in south-western Nigeria about $120 \mathrm{~km}$ east of the border with the republic of Benin, $128 \mathrm{~km}$ inland North-East of Lagos and 530km southwest of Abuja. Its population is 2,550,593 according to the 2006 census result including 11 local government areas. The population of central Ibadan, including five L.G. As is 1,338,659 according to the census result of 2006. The area under consideration lies between longitude $3^{\circ} 30^{\prime} \mathrm{E}$ to $4^{\circ} 00^{\prime} \mathrm{E}$ and latitude $7^{\circ} 00^{\prime} \mathrm{N}$ to $7^{\circ} 30^{\prime} \mathrm{N}$.

The study area covered $55 \mathrm{~km}$ by $55 \mathrm{~km}$ which is 3,025 square kilometers. This is shown in (Figure 1).

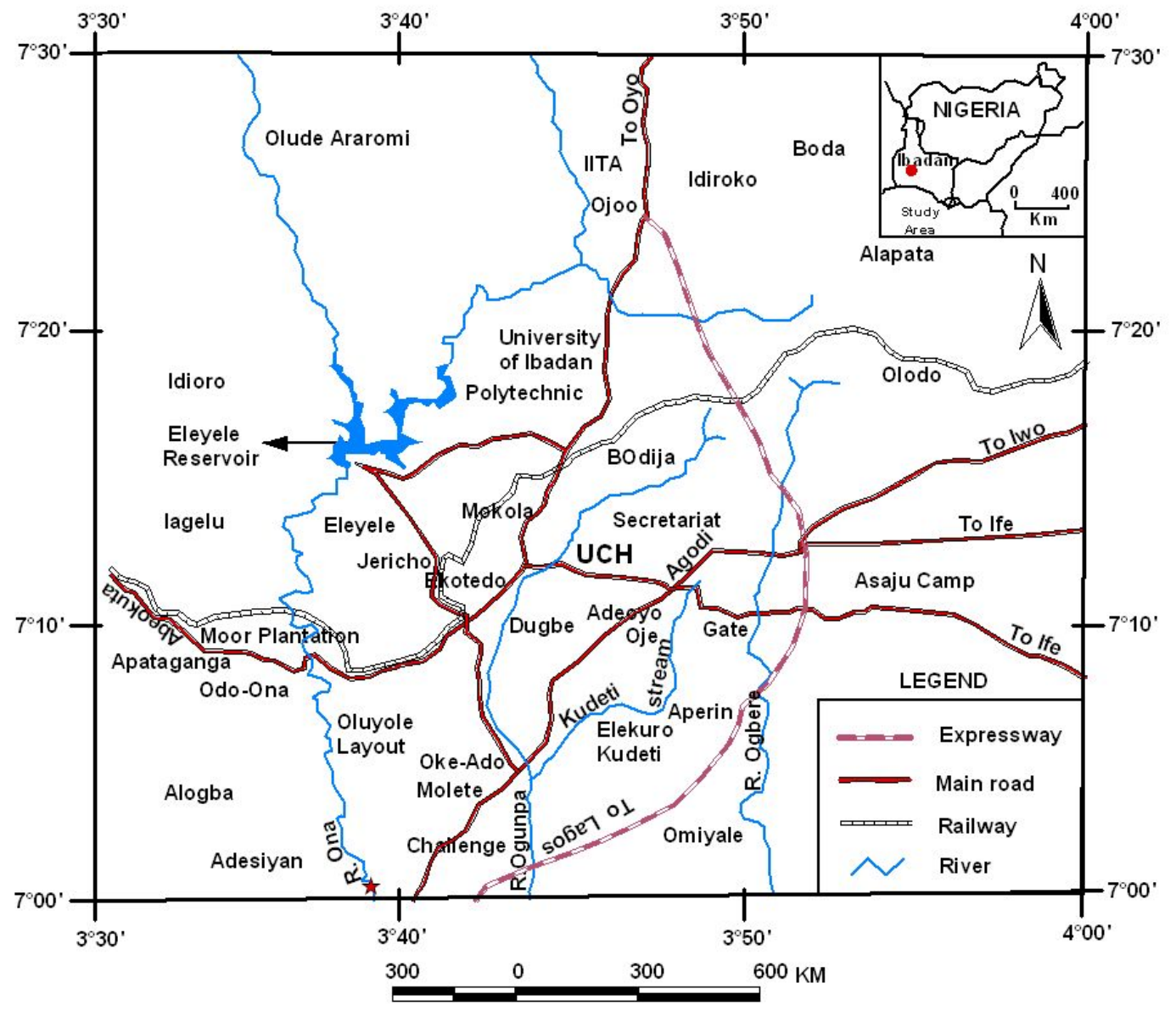

Figure 1. Location map of the study area 


\subsection{Basement Complex}

Oyo state is underlain by Precambrian rocks which forms part of the basement complex of south-western Nigeria. Ibadan falls within the basement complex of the geological setting of south-western Nigeria characterized by the basement complex rocks of the pre Cambrian age which are made up of the older and younger granites and the younger and older sedimentary rocks of both the tertiary and secondary ages.

Ibadan area is underlain by biotite granite gneiss, migmatite biotite gneiss, biotite muscovite granite, hornblende granite and schists. These crystalline rocks are composed primarily of banded gneiss in which the hornblende-biotite rich bands alternate with quartz-oligoclase rich bands. The banded gneiss, which originated as part of a sedimentary sequence, contains large lenses of granite gneiss and thin intercolated layers of quartzite and amphibolite (Adetoyinbo et al., 2010).

The Schistose rocks occurrences around Ibadan area constitute the southern extension of the North-south trending Iseyin Oyan belt. The schistose rocks are associated with an almost N-S trending unit of the migmatite gneiss complex. The contacts are tectonic in places with prominent slickenside features and cataclastites. These units were later intruded by Pan-African granitic rocks of adammellitic and pegmatitic varieties. These schistose rocks are mainly quartz schist and amphibole schist. The quartz schist form prominent features especially west of Ajibode and Sango area (Okunlola et al., 2009).

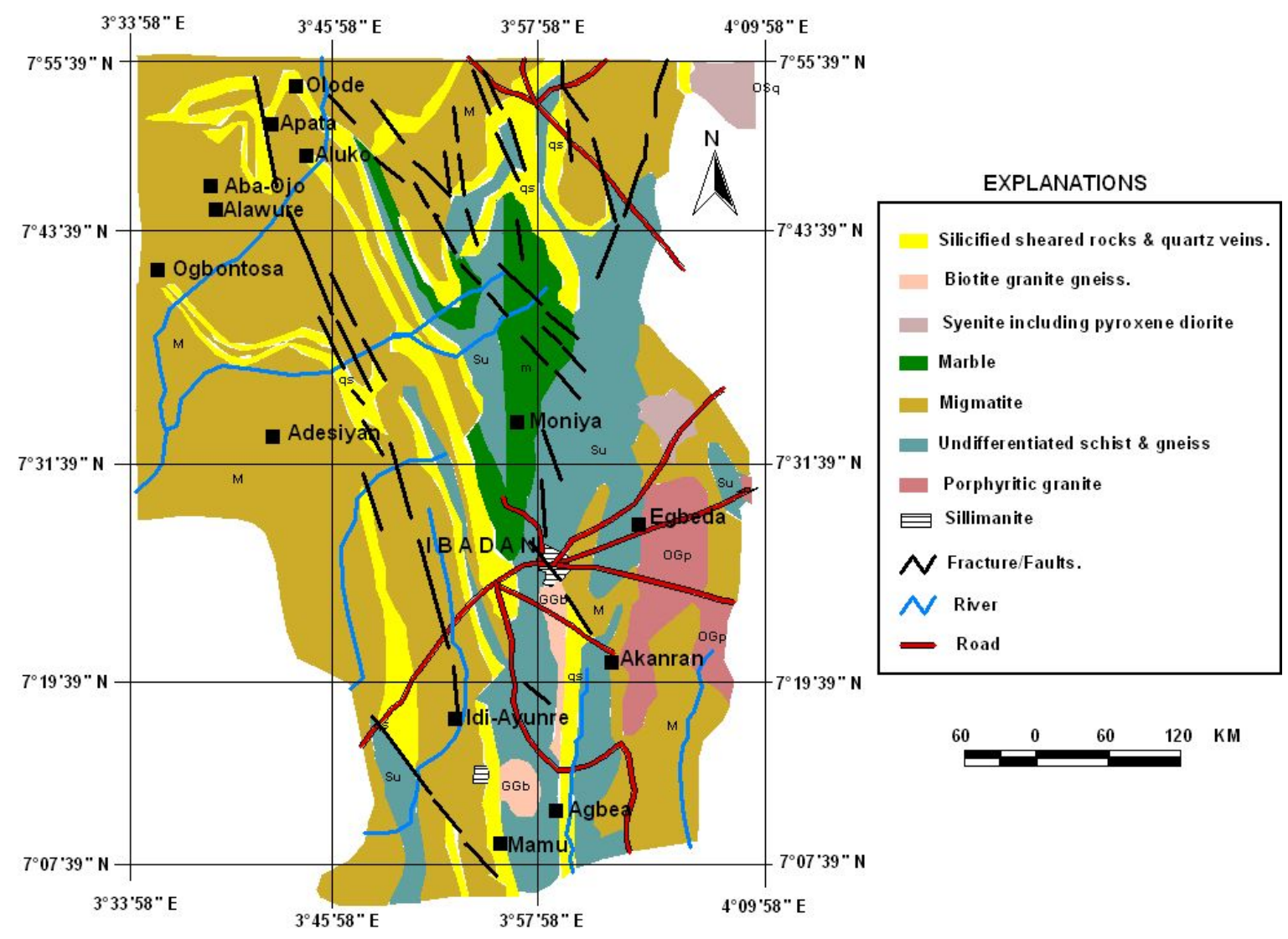

Figure 2. Geological map of the study area

The basement complex is one of the three major litho-petrological components that make up the geology of Nigeria. Within the basement complex of Nigeria, four major petrolithological units are distinguishable namely: the migmatite - Gneiss complex, the schist belt, the older Granite and the undefined Acid and Basic dykes. Ibadan falls under Precambrian basement.

The migmatite-Gneiss complex is generally considered as the basement complex that is most widespread of the component units in the Nigeria basement. It has a heterogeneous assemblage comprising migmatites, orthogeneises, paragneisses, and a series of basic and ultrabasic metamorphosed rocks. The migmatite-Gneiss 
complex has ages ranging from Pan-African to Eburnean. It makes up about $60 \%$ of the surface area of the Nigerian basement (Rahaman \& Ocan, 1978).

These rocks records three major geological events: the earliest at 2,500Ma involves initiation of crust forming processes (e.g the banded Ibadan grey gneiss of mantle origin) and of crustal growth by sedimentation and orogeny; next came the Eburnean, $2000 \pm 200 \mathrm{Ma}$, marked by the Ibadan type granite gneiss; this was followed by ages in the range from 900 to $450 \mathrm{Ma}$ which represent the imprint of pan African event and also gave rise to granite gneisses, migmatites and other similar lithological units (Obaje, 2009).

\subsection{Enhancement Process}

\subsubsection{Reduction to Pole}

This method entails removing the dependence of magnetic data on the magnetic inclination i.e. converting data which were recorded in the inclined Earth's magnetic field to what they would have been if the magnetic field had been vertical. This method simplified the interpretation because for sub-vertical prisms or sub-vertical contacts (including faults), it transforms their asymmetric responses to simpler symmetric and antisymmetric forms. The symmetric "highs" are directly centred on the body, while the maximum gradient of the antisymmetric dipolar anomalies coincides exactly with the body edges. This operation is usually required for magnetic data at low latitude. The RTP was performed on the digitized aeromagnetic data of the study are via fast Fourier filtering programs in order to remove the dipolar nature of the magnetic field.

\subsubsection{Upward Continuation}

This is a mathematical technique that project data taken at an elevation to a higher elevation.

The effect is that short wavelength features are smoothed out because one is moving away from the anomaly. Upward continuation is a way of enhancing large scale (usually deep) features in the survey area. It attenuate anomalies with respect to wavelength; the shorter the wavelength, the greater the attenuation. It is a way of enhancing large scale (usually deep) features in the survey area. Also upward continuation tends to accentuate anomalies caused by deep sources at the expense of anomalies caused by shallow sources (Mekonnen, 2004).

The upward continued $\Delta F$ (the total field magnetic anomaly) at higher level $(\mathrm{z}=-\mathrm{h})$ is given by,

$$
\Delta F(x, y,-h)=\frac{h}{2 \pi} \iint \frac{\Delta F(x, y, 0) d x d y}{\left(\left(x-x_{0}\right)^{2}+\left(y-y_{0}\right)^{2}+h^{2}\right)^{\frac{3}{2}}}
$$

Thus, the problem of calculating the field at higher level from the knowledge of the field at a lower level is a straight forward one of numerical integration of the surface data. In practice, the computations are made by replacing the surface integral with a weighted sum of values taken on a regular grid. The empirical formula (Henderson, 1960) given the field at an elevation $h$, above the plane of the observed field $(\mathrm{z}=0)$ in terms of the average value $\Delta \mathrm{F}$ (ri) over a circle of radius ri centred at the point $(\mathrm{x}, \mathrm{y}, \mathrm{o})$ multiplied by the appropriate weighting coefficients. These coefficients enable calculation of the upward continued field to an accuracy of within $2 \%$ (Sharma, 1976).

\section{Result and Discussion}

After performing the Reduction Pole (RTP) filtering operation on the gridded data for this work, it was apparent that the contour shows a significant change on comparison to the unfiltered contoured map which is a combined signals of regional, residual and noise. RTP map is smoother and defines the high and low centres better than the total intensity map (Figures 3 and 4 respectively).

Continuation filtering was also performed on the data with the use of FFTFIL and UCMALA. CMD prepared command file in respect to the distance of continuation. The upward continuation process was applied on magnetic data of Ibadan area at 1500, 1800, 2000 and 4000m to expose the basement at these various levels as shown in Figures 5, 6, 7 and 8 respectively. The upward continued data reveal increasing attenuation and broadening of the high wavenumber anomalies with increasing height above the study area.

These upward continued maps illustrate the change in anomaly character with increasing observation to magnetic source distance, and are also useful as a low-wavenumber pass filter. As such, the 4000m upward continued data provides an excellent integrated view of the study area undistorted by the local, high amplitude, high gradient anomalies of the magnetic sources in the shallow portion of study area. It is apparent that the attenuation of the shallow source anomalies in the upward continuation process permits a clearer or enhanced view of the deeper anomaly sources (Roberts et al., 1990). 
nT

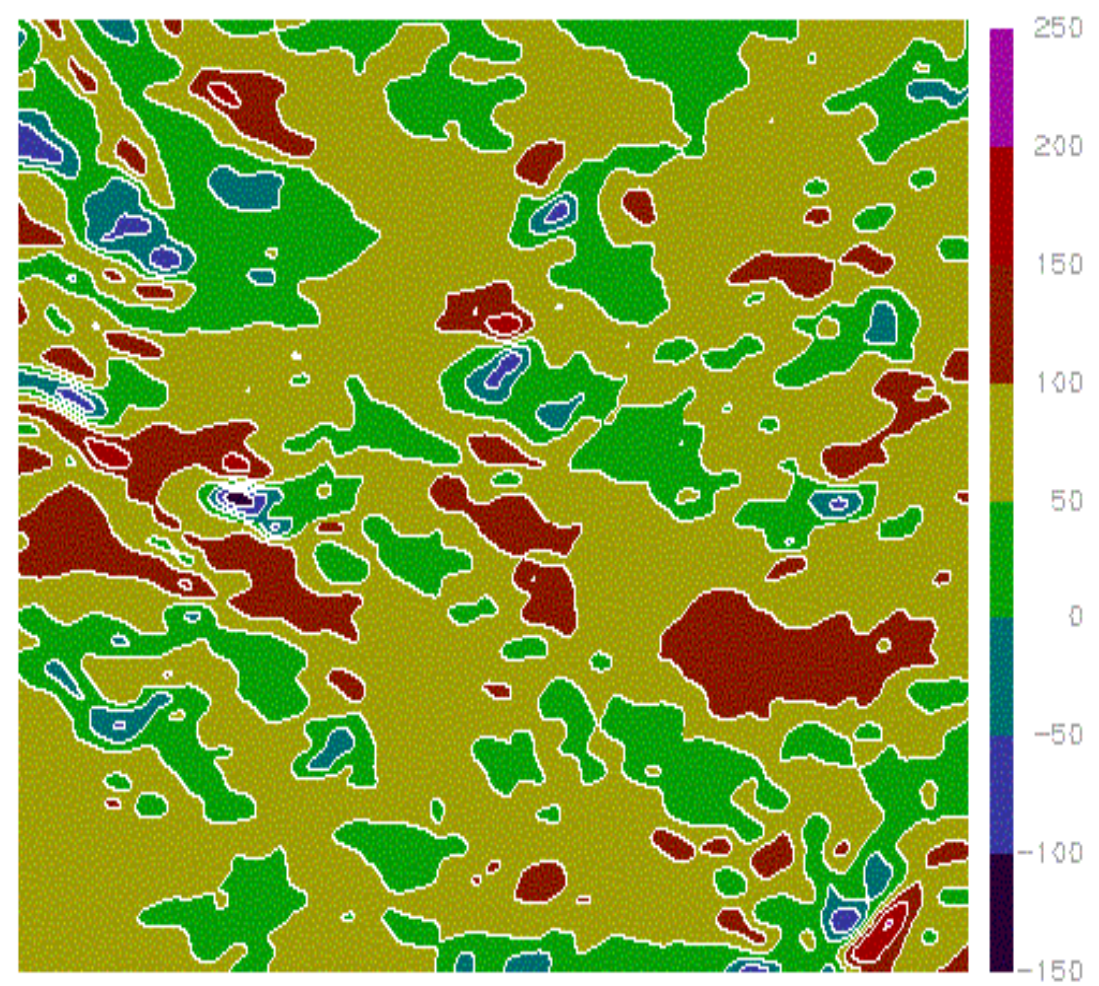

Figure 3. Raster contour map after RTP, Contour interval is 50nT

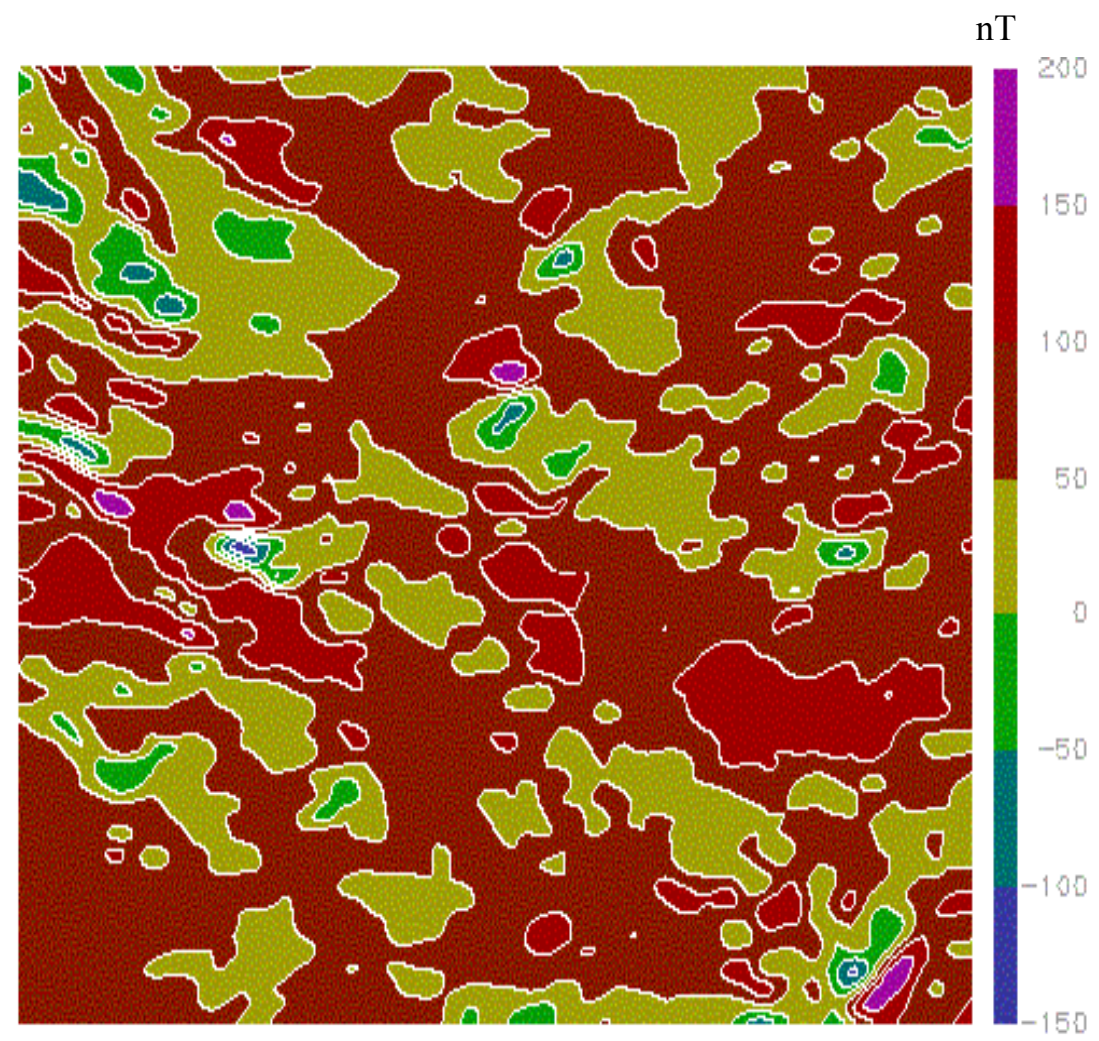

Figure 4. Raster contour map of the study area, Contour interval is $50 \mathrm{nT}$ 


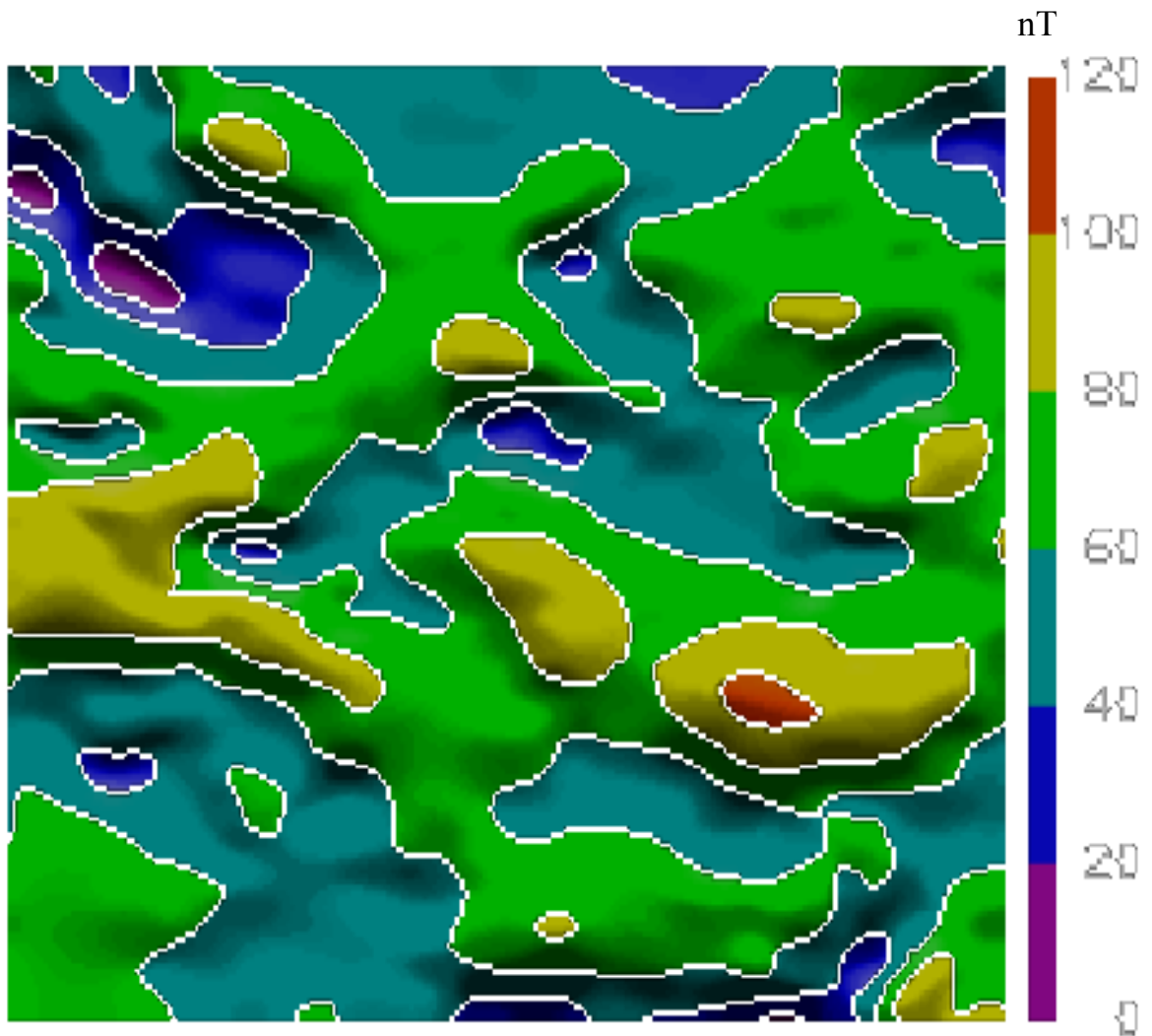

Figure 5. Upward continuation map for $1500 \mathrm{~m}$

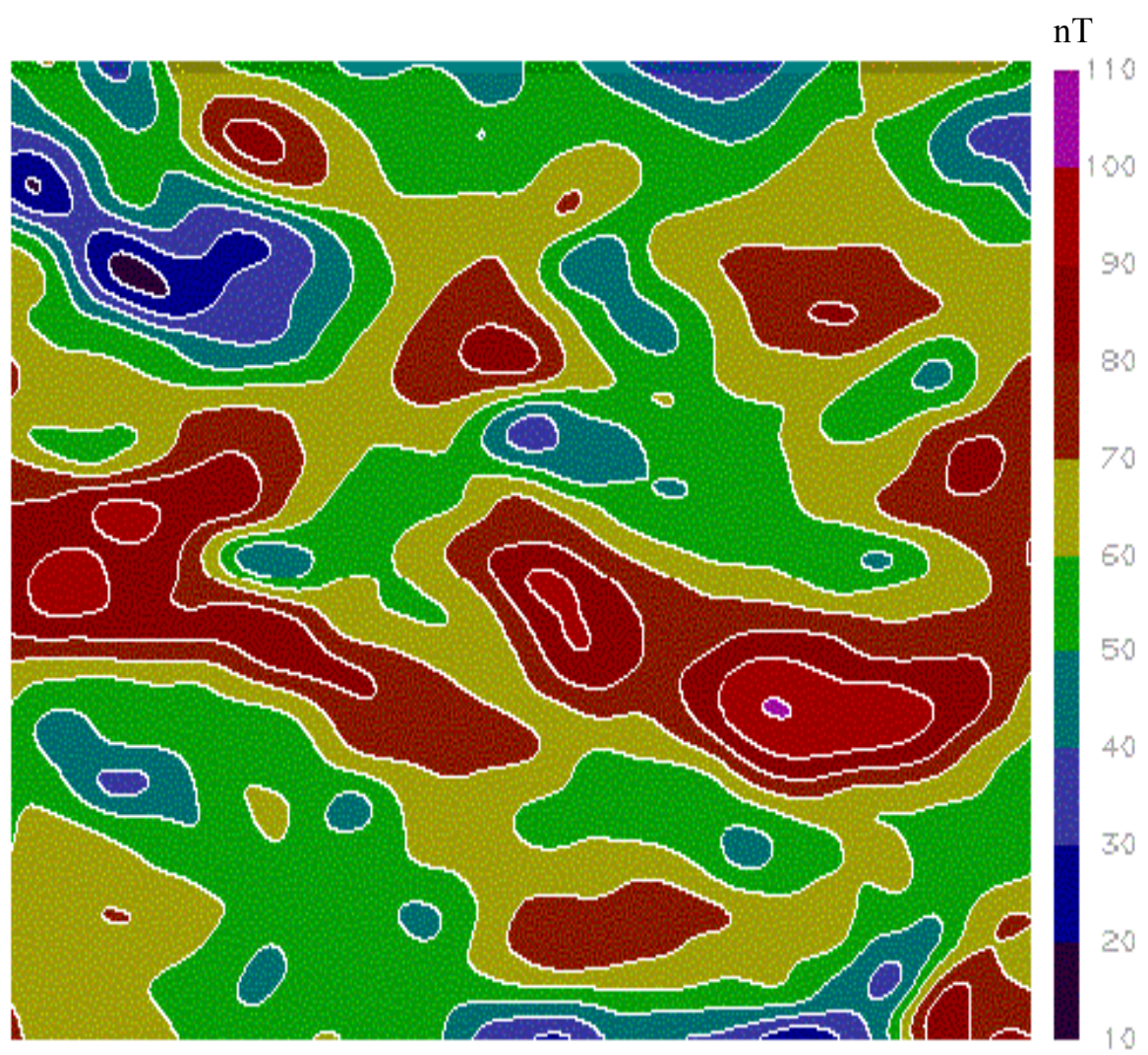

Figure 6. Upward continuation map for $1800 \mathrm{~m}$ 


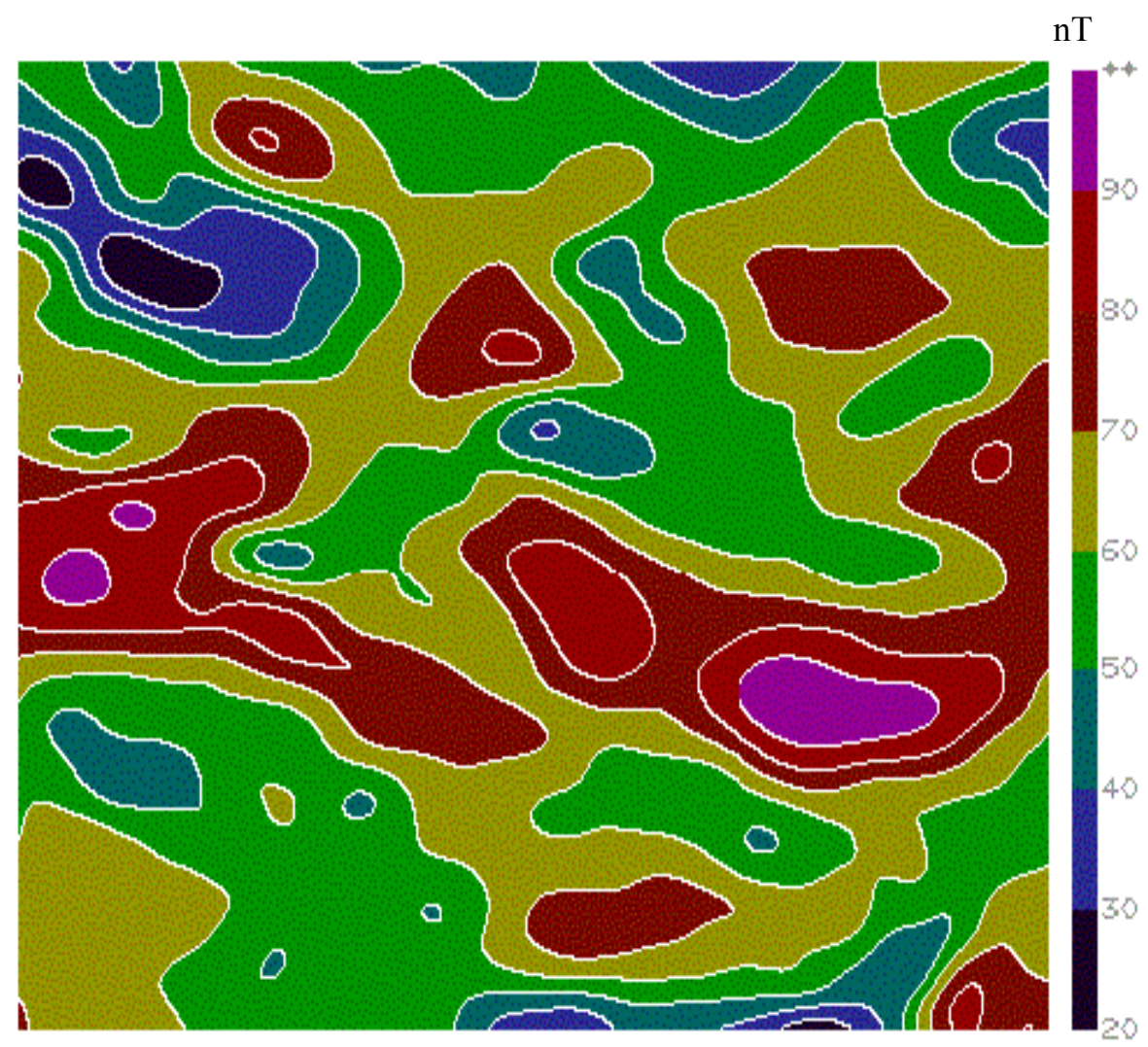

Figure 7. Upward continuation map for $2000 \mathrm{~m}$

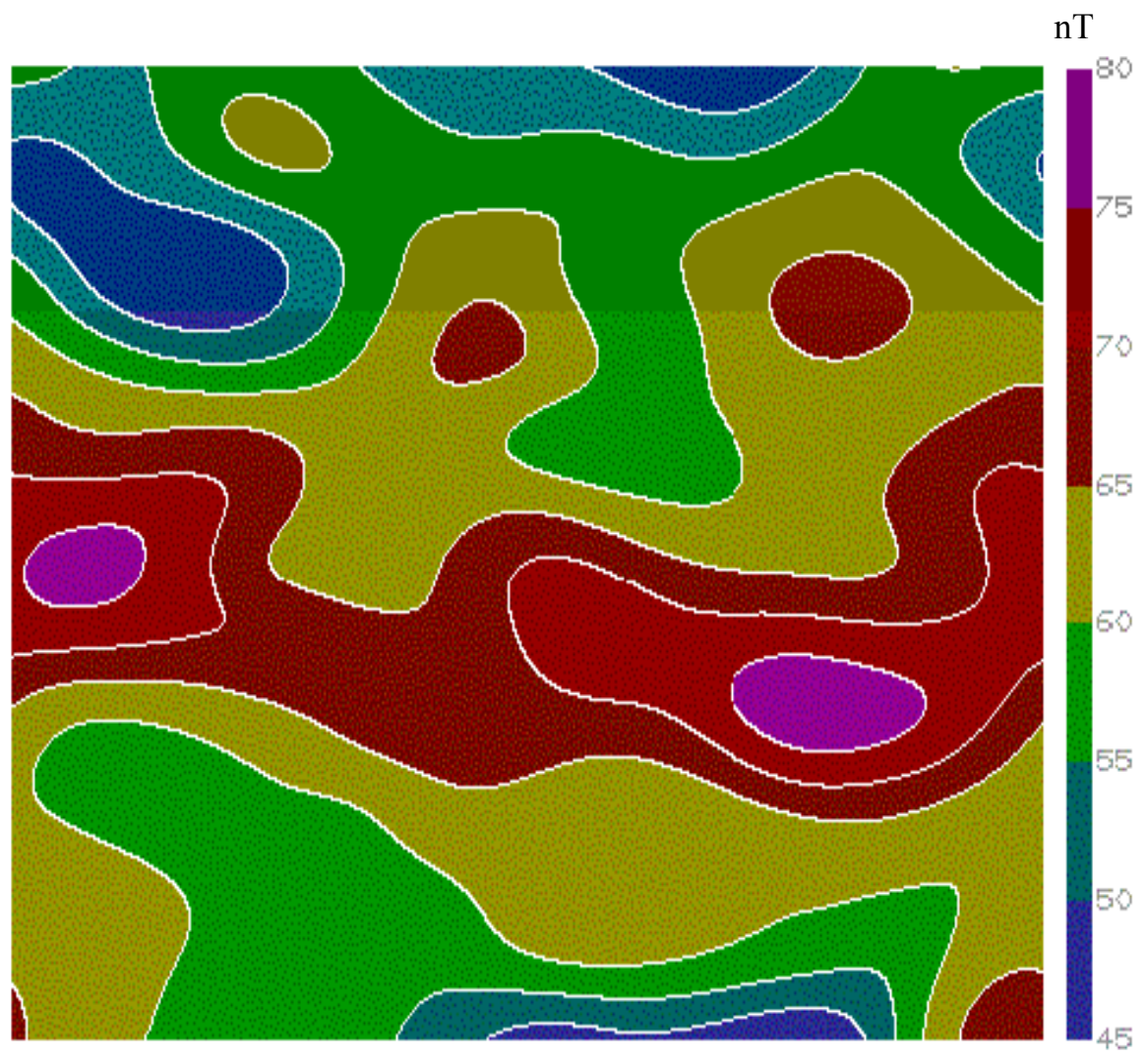

Figure 8. Upward Continuation map for $4000 \mathrm{~m}$ 


\section{Conclusion}

The Reduction to pole processing of magnetic data over Ibadan area defines the locations and spherical nature of sources better than the contour of the unfiltered total intensity magnetic data of the study area. The upward continuation process shows clearly the attenuation of short-wavelength anomalies with respect to the increase in observation to source distance. The Reduction to pole and upward continuation process therefore serve as an effective data enhancement procedure and aids these interpretations of the anomaly sources.

\section{Acknowledgment}

The authors acknowledge the Nigerian Geological Survey Agency, Abuja, Nigeria for the release of the aeromagnetic data used in the study.

\section{References}

Adetoyinbo, A. A., Popoola, O. I., Hammed, O. S., \& Bello, A. K. (2010). An Assessment of Quarry Blasting vibration impacts in Ibadan and Abeokuta, Nigeria. European J. of Scientific Research, 4(2), 228-252.

Birch, F. S. (1984). Bedrock Depth Estimates from Ground Magnetometer Profiles. Groundwater, 22(4), 427-432. http://dx.doi.org/10.1111/j.1745-6584.1984.tb01413.x

Herderson, R. G. (1960). A Comprehensive of Automatic Computation in Magnetic and Gravity Interpretation. Geophysics, 25, 569-585.

Jacobsen, B. H. (1987). Acase for upward continuation as a standard separation filter for potential-field maps. Geophysics, 52, 1138-1148.

Mekonnen, T. K. (2004). Interpretation and Geodatabase of Dukes using Aeromagnetic data of Zimbabwe and Mozambique. M. Sc. Thesis, International Institute for Geoinformation science and Earth Observation, Enschede, the Netherlands. Retrieved from http://www.slideserve.com/phila/partners

Obaje, N. G. (2009). Geology and Mineral Resources of Nigeria. Lecture Note in Earth Science Series Volume 120. http://dx.doi.org/10.1007/978-3-540-92685-6

Okunlola, O. A., Adeigbe, O. C., \& Oluwatoke, O. O. (2009). Compositional and Petrogenetic features of schistose rocks of Ibadan area, Southwestern Nigeria. Earth Sci. Resources Journal, 13(2), 119-133.

Phillips, J. D. (1997). Potential Field Geophysical Software for the PC, verson 2.2 U.SGS open-File Report 97-725.

Rahaman, M. A., \& Ocan, O. (1978). On the Relationship in the Precambrain Migmatite Gneiss of Nigeria. Journal of Mining Geol., 15(1), 23-32

Roberts, R. L., Hinze, W. J., \& Leap, D. I. (1990). Data enhancement Procedure on magnetic Data from Landfill Investigations. 261-267.

Sharma, P. V. (1976). Geophysical Methods in Geology. Amsterdam-Oxford New York: Elservier Scientific Publishing Company.

Walsh, D. C. (1989). Surface geophysical exploration for buried drums in urban environments applications in New York City in Proc of the Third Nat Outdoor Action Conf. on Aquifer Restoration, Groundwater Monitoring and Geophysical Methods, Orlando 935-949. 